骨, 関節の変形性変化の成因については, 機械的機 能的発生説, 血行障碍説, 局所阻血説, 年令的要素 (即ち老化現象), 素团, 内分泌異常等之諸説が述べら れ定説はないが，動脈硬化を基底とした血行障碍との 関連性が問題之なつている現在, 老人病の一端を占め る変形性脊椎症求よび変形性関節症等の整形外科的疾 患の治療にも新しい薬剂の出現が望まれている.

内科的飞高脂血症 Hyperlipemia および高脂血症 に基く動脈硬化症に効果の浔められるMDS を使用 し, 関節内泟入および脊䯣腔内注入に於てはステロイ ド剂と同様の効果を示し, また内服, 静注, 局注に於 てもかなりの効果が期待出来るので, 今後なお広く適 応を選び, 更に種々の疾患使用すれば面白い結果を 得るととが出来るものと思われる.

（終りに臨み, 御指導と御校閲を頂いた恩師玉井達 二教授に感謝の念を㥭げ, 薬品の提供を曼けた興和新
薬株式会社に謝意を表す)

\section{文献}

1）横崎：日整会誌. $38: 1$, p. 1 .

2）志村：日整会誌. $38: 3$, p. 51 .

3）佐藤・他：日整会誌. $36: 7$, p. 57 .

4）高橋：日整会誌. $37: 12$, p. 1 .

5) 岩原: 外科治療. $4: 4$, p. 99.

6）天児：臨林と研究. $41: 3$, p. 1.

7) 西: 臨牀と研究. $41: 3$, p. 7.

8）永井: 臨牀と研究. $41: 3$, p. 21.

9）ATP の基礎と臨林（1962 年第 3 回 ATP 研究 総会满演記録）p. 185.

10）ATP の基礎と臨林（1963年第 4 回 ATP 研究 総会講演記録）p. 155.

11）松本・他：皮眉科の臨牃. $5: 8$, p. 1 .

12）山崎：日整会誌. $33: 6, p .81$.

13）中原：日整会誌. $34: 6$, p. 113 .

14）森・他：日整会誌. $36: 10$, p. 69.

\title{
副腎皮質ホルモン使用による2，3の 教訓的症例について
}

長崎原爆病院整形外科

$\begin{array}{lllll}\text { 三 } & \text { 原 } & \text { 茂 峰 高 嶺 } \\ \text { 山 } & \text { 口 重 } & \text { 嘉 } & & \end{array}$

\section{Bone and Joint Injuries resulting from Adenocortical Steroid Therapy \\ By \\ S. Mihara, J. Mine and S. Yamaguchi \\ Orthopedic Clinic, Nagasaki Atomic \\ Bomb Hospital}

1948年 Hench らによつてコーチゾンがリウマチ性 疾患に著効を呈することが発表されてから，ステロイ ドに対する一般の認識屯急速にたかまり, 続々と新し いステロイドが合成され，ひろく臨床各科に利用され ていることは周知の通りである. しかしながらその後 の臨床的経験によりステロイドの効果の限界と副作用 が次第に明確にされ種々の反省と検討がなされる様に なつて来た。

ステロイドの連用による骨関節に及ぼす影響は一般
的には表 1 の如くであるが, 今回吾々は整形外科領域 にとくに関係の深い 2 つの問題を取上げて検討してみ

表 1 Iatrogenic disease of the skeleton resulting from adrenocortical steroid therapy
1) Cushing's syndrom
2) Osteoporosis, fractures, and joint degeneration
3) Bone and joint infections
4) Delay in skeletal development 
たいと思う。

その一つは主としてステロイドの関節内注入による 感染の問題であり, 他の一つは感染症の誘発ないしは 増悪の問題である.

以下それぞれ吾々の経験した症例を中心に論ずるこ とにする。

表 2

関節内注入に上る感染例

\begin{tabular}{|c|c|c|c|}
\hline No. & 患 & 者 & \\
\hline \begin{tabular}{l|}
1 \\
2 \\
3 \\
4 \\
5
\end{tabular} & $\begin{array}{l}36 才 \\
50 才 \\
24 才 \\
67 才 \\
68 才\end{array}$ & $\begin{array}{l}\hat{1} \\
\hat{0} \\
0 \\
0 \\
\hat{3} \\
\hat{0}\end{array}$ & 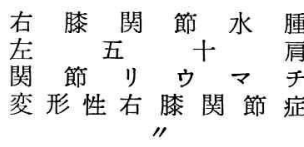 \\
\hline
\end{tabular}

全身投与による感染症増悪例

\begin{tabular}{|c|c|c|c|}
\hline $\begin{array}{r}6 \\
7 \\
8 \\
9 \\
10\end{array}$ & $\begin{array}{r}22 才 \\
7 才 \\
8 才 \\
5 才 \\
10 才\end{array}$ & 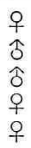 & $\begin{array}{l}\text { 右 膝関 節 結 核 } \\
\text { 急性膿性右股 関節炎 } \\
\text { 左大腿 骨々 䯣炎 } \\
\text { 左大腿骨々䯣炎兼病的骨折 }\end{array}$ \\
\hline
\end{tabular}

表 2 に示す様に吾々が経験したステロイド障害と思 われる症例は 10 例である.ささてその 1,2 について説 明すると，

\section{症例 $4: 67$ 才}

約 3 年位前から右㳟に倦急感があり, 次第に歩行痛 を感ずる様になつたので某医に受診し，関節穿刺とプ レドニンの関節内注入療法をうけている. 約 1 年間と の治療をくりかえしたが軽快しないので, 更に転医し て同じ様に週 1 回の関節穿刺とプレドニンの関節内注 入を約 1 年間行つており, その間に感染の機会があつ たあのと思われる.すなわち治療途上において患側大 腿遠位部に突然疼痛之腫脹がおこり筋炎の診断のもと に切開をうけている事実があつて，それを契機として 関節炎の症状が増悪したと云う，关の後運動ならびに 歩行障害が增強する傾向にあつたので，感染の機会上 思われる時から 8 力月後に吾々の外来に受診したもの である。

初彰時右膝関節は滑膜の肥厚が著明で, 軽度の熱感 はあるが, 発赤圧痛等は軽度であつた. 血沈中等価 80 , CRP (6+), RA (-), 白血球 10,450 で化膿性関節炎 と部断された。しかし穿刺液加らの菌の検出は陰性 で, 滑膜の組織㭘查では Synovitis rheūmatica mit chronische Stadiūm と云う病理診断を得た. レ線像

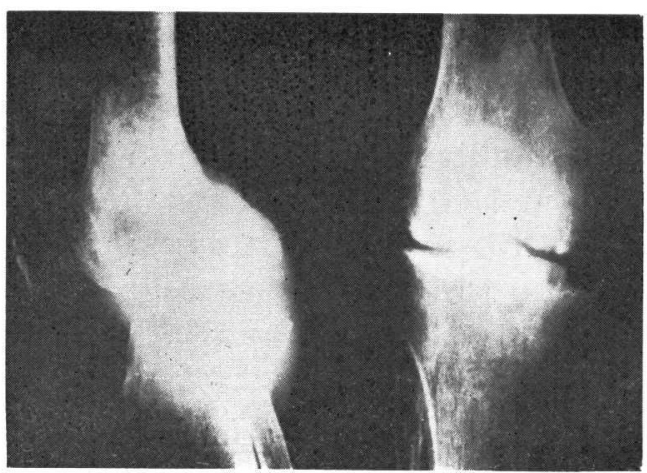

図 1

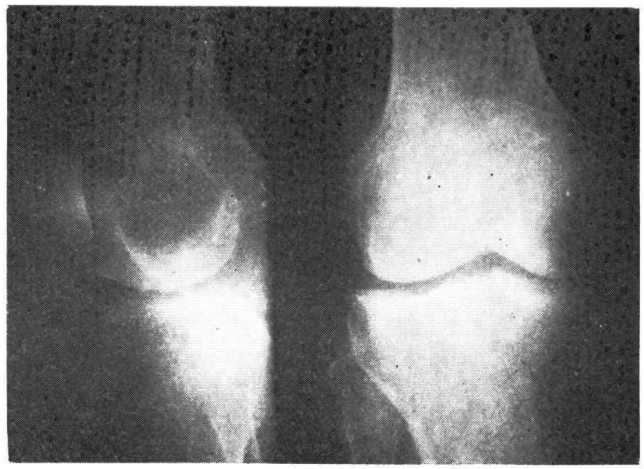

図 2

では滕関節内側部の骨破壊像がみられとくに脛骨内側 関節面に著明である. 又一般に骨萎縮と硬化の錯走せ る像がみられる．前医の好意により借用したレ線像で は上記の骨破壊はなく明らかに変形性関節症の所見で ある (図 1 及 2 ). 本症例飞対しては強力な化学療法 を行うと共に保持用装具を装用させているが必ずしも 良好な経過をたどつていない。なお後日関節液より少 量の黄色ブドー球菌を証明している.

本症例が示す様にステロイド注入による感染性化膿 性関節炎は，ステロイドの强力な抗炎症効果のかげに かくれて関節構成物を一層高度な破壊に進展せしめる 危険がきわめて大きいと考えられる. Hollander は 10 万回の注入によつて14関節に感染をおてしたよのべて いるが，か〉る障害は吾々整形外科医としては甚だ不 名誉なととであり立分に注意する必要があると思う。

又最近欧米では関節内注入によつて神経病性関節症 類似の関節障害がおてると云う報告がみられており， あわせて一般の関心をたかめたいと思う．次に

症例 $10: 10$ 才女 
昭和 37 年 12 月はじめ発㤵之其に左㮦が腄脤し, 某 医により関節第刺をうけている。しかし歩行は次第に

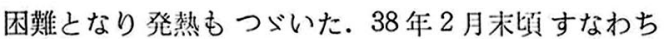
発症後約 3 力月の頃つまづいて転倒し歩行不能となつ

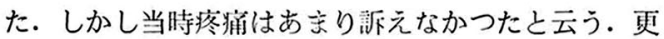
に 1 力月後左大腿遠位部の屈曲を来すに至つたので受 䛦したものである。それまでの治療内容はプレドニン 1 日 $15 \mathrm{mg}$ ，テトラサイクリン系薬剂 $750 \mathrm{mg}$ を併用 して服用しており，多分にリウマチ熱と誤認して加療 した傾向がうから゙われる.

診断はレ線で明らかな様に左大腿骨骨䑧炎と病的骨

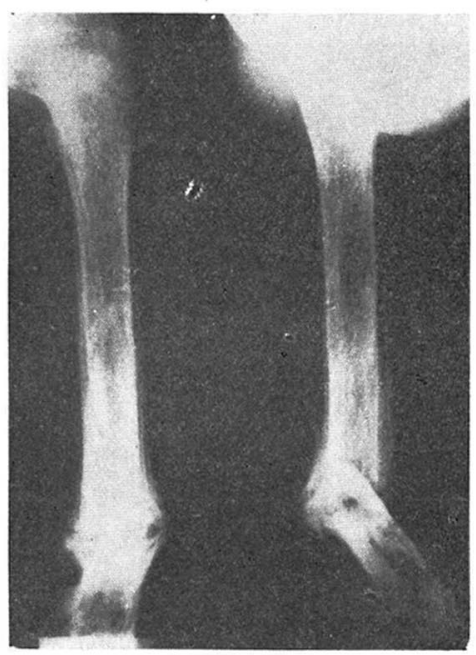

図 3

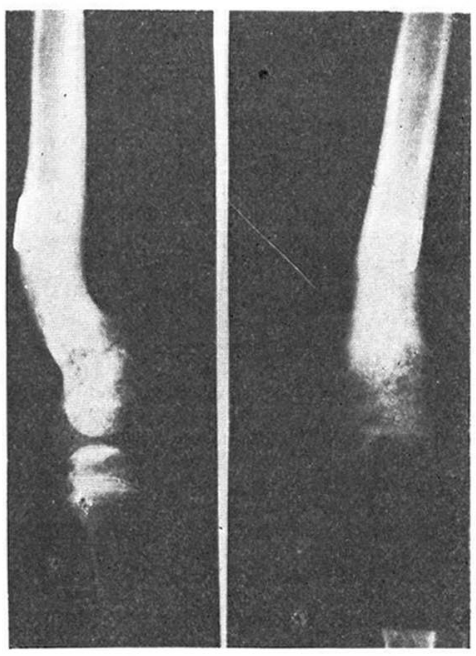

图 4
折である．治療は強力な化学療法のもとに腐骨摘出骨 接合術を抬行し 4 力月後に限院した（図 3 及 4 ）。

本症例の場合は更に一層教訓的なむのを吾々に示し ている.すなわち感染症に対しあやまつてステロイド を投与した場合，感染の不顕性化と增悪と云う問題で ある. 本症例の病歷中はじめ関䬣穿刺を行つたと云う 事実があるが医師は骨崄炎の存在には殆んよ゙関心を払 つていなかつたものと考えられる. しかむステロイド の強力な抗炎症作用のために咀盏炎の特徽的な局所々 見も乏しく，てれを看過しついて病的骨折にまで進展 させんものと想像される. しかも本症例はステロイド 之共にかなり強力な抗生物質を併用しているにもか〉 わらず，骨破壊の進展を阻止することは困難ではなか つたかと考えられる点もあり，ステロイドを投与する 場合にはとくに慎重に適応を決定することが必要であ ると痛感する.

以上整形外科領域においてステロイド使用による障 害について吾々の経験した症例を中心に報告した。ス テロイドは臨床上今後益々使用される傾向にあるの で, 感染の防止や適応の決定について充分配虑する必 䛠があると思う。

\section{文献}

1) Chandler et al.: Lancet., II : 661, 1958.

2) Chandler et al.: Brit. med. J., I : 952, 1959.

3) Sweetnam: Brit. med. J., I : 1362, 1960.

4) Murray, R. O.: Radiology., $77: 729,1961$.

5) Steinnberg et al.: Arbitis \& Rheum., 5 : 659, 1962.

追 加九大山本真

骨, 関節の感染症については, その起炎菌に明らか に有效之考えられる抗生物質をかなり大量用いていて あ副堅皮質ホルモンを用いると感染が增悪するといつ て症例が多いという経験から，他科の領域における併 用療法上異り，上り大きく注意を要すると考えるので 追加する.

答長崎原爆病院 三 原茂

数年前に陳回性脊椎力リエスに対する化学療法とス テロイドの作用療法について報告したことがあるが, この時は保存的にも手術的にも治療の行きづまりにあ る栐な症例に対してステロイドを短期間使用して良効 成繶を得たものである. しかし一般的には骨関節の化 膿性感染症に対しステロイドを使用することはさけね ばならないと考えている. 